\title{
Самый большой аппликационный буддийский свиток из фондов Национального музея Тувы
}

\author{
Ульяна П. Бичелдей \\ Тувинский институт гуманитарных и прикладных социально-экономических исследований \\ при Правительстве Республики Тыва, Российская Федерация
}

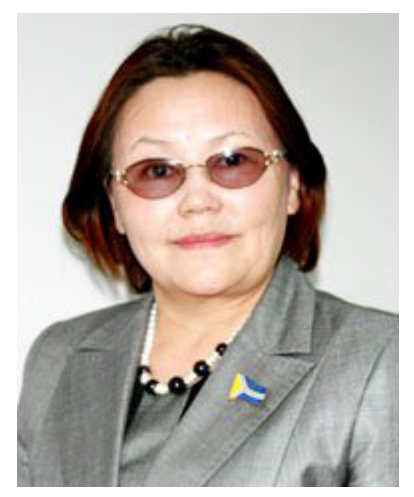

Творчество тувинских мастеров в русле традиций буддийской иконографии ведет отсчет истории со второй половины XVIII в. Оно имеет свои локальные особенности, в отличие от методов монгольских художников. В фондах Национального музея им. Алдан-Маадыр Республики Тыва хранятся три буддистских свитка (иконографические изображения на ткани), выполненных техникой аппликации. Среди них особо выделяется аппликационное иконографическое изображение буддииского божества достаточно большого размера. Она имеет значение и как ценный источник по религиозной культуре, и как священная реликвия региона. Статья вводит в научный оборот информацию о не изученных реликвиях, и вносит вклад в исследования храмового искусства Тувы.

Даны основные сведения о всех трех аппликационных свитках (время поступления, время создания, описание изображения), в том числе их фотографии. Самый большой свиток был сдан в хранилище музея в июне 1960 г. вместе с другими многочисленными предметами буддийского культа, после конфискации имущества молитвенных юрт местечка Кызыл-Чыраа Дзун-Хемчикского района. Описан оклад свитка, изображение трехликого божества белого цвета с четырьмя руками, облаченный в прекрасное одеяние. Предполагается, что это одна из ипостасей бодхисаттвы безграничного сострадания Авалокитешвары.

Сделан вывод, что данная аппликация, возможно, была изготовлена на территории Тувы усилиями местных мастеров с использованием китайского материала.

Ключевые слова: буддийская храмовая живопись; тханка; буддийская икона; буддийский свиток; аппликационная тханка; Национальный музей Тувы; Тува

\section{Для цитирования:}

Бичелдей У. П. Самый большой аппликационный буддийский свиток из фондов Национального музея Тувы [Электронный ресурс] // Новые исследования Тувы. 2019, № 2. URL: https://nit.tuva.asia/nit/article/view/854 (дата обращения: дд.мм.гг.). DOI: 10.25178/nit.2019.2.14

Бичелдей Ульяна Павловна - доктор религиоведения (Ph.D), руководитель группы религиоведения Тувинского института гуманитарных и прикладных социально-экономических исследований при Правительстве Республики Тыва. Адрес: 667000, Россия, г. Кызыл, ул. Кочетова, д. 4. Тел.: +7 (394-22) 2-39-36. Эл. адрес: opei-ool@yandex.ru ORCID ID: 0000-0001-5588-9167

Bicheldey Ulyana Pavlovna, Doctor of religious studies (Ph.D), Head, Religious studies unit, Tuva Institute for the Humanities and Applied Social and Economic Studies. Postal address: 4 Kochetov St., 667000 Kyzyl, Russian Federation. Tel.: +7 (394-22) 2-39-36. E-mail: opei-ool@ yandex.ru 


\title{
The largest appliqué Buddhist scroll in the collections of the National Museum of the Republic of Tuva
}

\author{
Ulyana P. Bicheldey \\ Tuvan Institute for the Humanities and Applied Socioeconomic Studies, Russian Federation
}

\begin{abstract}
Tuvan craftsmen had been following the traditions of Buddhist iconography since the latter half of the 18th century. Their work has its distinctive local features, setting it apart from the methods employed by their Mongolian counterparts. The AldanMaadyr National Museum of the Republic of Tuva has in its collections three Buddhist thangkas (iconographic compositions on textile) made in the technique of the appliqué. Among the three, one stands out - a large appliqué image of a Buddhist deity. It is significant both as a valuable source of information on religious culture of the region and as its sacred object. This article for the first time describes some of the understudied relics, also offering a contribution to the studies of Tuva's religious architecture. Provided are the metadata on each of the three appliqué thangkas (acquisition date, time of creation, description of the imagery), accompanied by their photographs. The largest of the three thangkas were donated to the museum in June 1960, together with a number of other ritual objects confiscated from the prayer yurts of Kyzyl Chyraa in Dzun-Kemchik rayon. Also described is the piece of cloth encasing the appliqué. It features a three-faced deity with four arms clad in a beautiful garmentprobably an avatar of bodhisattva Avalokiteśvara (Padmapani) of endless compassion.

The article concludes that appliqué could have been made by local craftsmen in Tuva, while the textiles must have come from China.
\end{abstract}

Keywords: Buddhist religious decorative art; thangka; Buddhist icon; appliqué thangka; Buddhist scroll; National Museum of the Republic of Tuva; Tuva

\section{For citation:}

Bicheldey U. P. The largest appliqué Buddhist scroll in the collections of the National Museum of the Republic of Tuva. The New Research of Tuva. 2019, № 2. URL: https://nit.tuva.asia/nit/article/view/854 (access date ...). DOI: 10.25178/nit.2019.2.14

\section{Введение}

Тува является одной из трех буддийских регионов Российской Федерации, население которой - тувинцы, - будучи тюркоязычным народом, традиционно исповедуют буддизм. Обосновавшись в регионе во второй половине XVIII в., претерпев сложные и драматические исторические события XX века, буддизм по настоящее время продолжает оставаться важнейшей основой духовной культуры тувинцев. За более чем 200-летнюю историю присутствия буддизма на территории Тувы, здесь в достаточной мере получил развитие один из видов религиозной творческой культуры - храмовая живопись.

Храмовое искусство в Туве, в целом, является малоизученной темой. Из числа исследователей этому направлению должное внимание уделила только Т. Б. Будегечиева (Будегечи, 1995, 2018). Исследуя историю храмовой живописи у тувинцев, она сделала вывод, что истоки изобразительности на территории Тувы, представленные в различных традиционных ремеслах, уходят в глубокую древность. Развиваясь с течением времени, они впитывали в себя тысячелетний эстетический опыт народа, весь его художественный генофонд (Будегечиева, 2018: 89). При этом она совершенно справедливо отмечает, что в этом направлении имеются вопросы, которые до сих пор остаются неизученными. Таким белым пятном, по ее мнению, в осмыслении изобразительного наследия тувинцев остается культовое искусство, в частности храмовая живопись (там же).

Помимо этого, ее работы представляют для исследователей ценность тем, что она впервые в истории исследования буддийского культового искусства Тувы представила информацию о тувинских мастерах по иконографии, храмовой оформительской работе и ремеслу. На основе изучения фрагментов буддийских сооружений, каменных и глинянных изваяний, рельефных и живописных изображений на скалах Тувы, Т. Б. Будегечиева сделала вывод о том, что в Туве подобные объекты буддийского культа более древних периодов создавались мастерами монгольских и китайских поселений. 
В фондах Национального музея им. Алдан-Маадыр Республики Тыва хранятся несколько буддийских свитков, выполненных техникой аппликации - посредством соединения разноцветных лоскутков шелка. Среди них особо выделяется аппликационное иконографическая изображение буддийского божества достаточно большого размера. Оно состоит из разноцветных лоскутков щелка и обшито в хлопчатобумажную ткань, служащего ему окладом. Высота шелковой аппликации с изображением божества -2 м 22 см., ширина -1 м 83 см. Высота всей картины с окладом составляет 4 м 35 см., ширина 2 м 42 cм.

Целью данной статьи является введение в научный оборот информации о хранящихся в музее свитках и представление самого большого из них - самого важного в коллекции главного музея Тувы. Он имеет значение и как ценный источник по религиозной культуре, и как священная реликвия региона.

\section{Буддийские свитки: общая справка}

Буддийские свитки (тханки) - вид особого храмового искусства, своеобразная буддийская икона, которой принято украшать святилища буддийской религии. В фондах тувинского музея хранятся свитки двух видов: рисованные на грунтованном куске полотна с тканевой основой и сшитые из лоскутков шелковой ткани.

В словаре буддийских терминов дается следующее толкование храмовой иконы, исполненной росписью: «танка, тханка, кутханг (тиб., букв. свиток) - в тибетском изобразительном искусстве изображение, преимущественно религиозного содержания, выполненное клеевыми красками или отпечатанное на шелке или хлопчатобумажной ткани, предварительно загрунтованной смесью из мела и животного клея» (Буддизм ..., 1992: 236-237).

Если учесть, что буддизм проник в Туву из Монголии (Кузьмин, 2016: 24-31) вместе с другими видами храмового искусства, то и техника грунтовки полотна, вероятнее всего, была заимствована тувинцами, прежде всего, от монголов. Действительно, исследователи истории тувинского буддизма отмечают несколько этапов проникновения его на территорию Тувы (Монгуш, 2001). Более детальное знакомство тувинских племен с буддизмом принято относить к IX в. - ко времени господства уйгурских племен (Берзин, 1992: 16). В связи с этим, Т. Б. Будегечиева предполагает, что с этого времени, возможно, стали появляться здесь и предметы буддийского культа, которые, в дальнейшем, продолжали поступать до господства в ней монгольских Алтын-ханов, Джунгарии и в последующие периоды (Будегечиева, 2018: 89, 90).

По мнению Т. Б. Будегечиевой, определенно о творчестве именно местного населения в русле традиций буддийской иконографии можно говорить начиная со второй половины XVIII в. - времени захвата Тувы маньчжуро-китайскими завоевателями, и до 30-х гг. XX столетия (там же: 90).

O технике изготовления тханки посредством нанесения рисунка из природных красок на грунтованное полотно подробно написано в книге монгольского искусствоведа Ням-Осорын Цултэма «Искусство Монголии» (Цултэм, 1984: 81). Автор подчеркивает, что в Монголии указанной техникой изготовления полотна, необходимой для написания красками картин на религиозные сюжеты, пользовались все живописцы. Н.-О. Цултэм писал, что после того, как работа над картиной завершалась, ее обрамляли в шелковое полотно. Цвет шелка, используемого для обрамления, должен был гармонировать с тоном картины. В верхний и нижний концы тханки вставляли круглые деревянные бруски - своеобразные штанги. За концы верхней штанги привязывали шнур, за который тханку подвешивали на стену храма. А нижняя штанга служила своего рода отвесом (там же: 97).

Описывая технику изготовления тханки тувинским мастером храмового иконотворчества (тув. чурукчу) Даваа Ондаром из Сут-Хольского кожууна, Т. Б. Будегечиева, будучи очевидцем, наблюдавшим работу мастера во время творческого процесса, выявила некоторые локальные особенности подготовки тханки, отличающиеся от методик монгольских художников. Например, указанный мастер во время приготовления клея для пропитки тканевой основы картины пользовался порошком, добытым из рогов марала (там же: 92). Или, тувинские мастера для палитры использовали обычные плоские камни (там же: 94).

Несомненно, в каждом из буддийских регионов были выработаны собственные локальные особенности в технике и манере исполнения нарисованных красками свитков. Искусствоведы в данной области без труда распознают - в какой мастерской была изготовлен тот или другой свиток. 


\section{НОВЫЕ ИССЛЕДОВАНИЯ ТУВЫ}

www.nit.tuva.asia

Одним из уникальных видов древнего буддийского искусства, наравне с нарисованными на грунтованном полотне картинами, является создание буддийских икон методом аппликации - аппликациионый свиток. Подобная техника также принадлежит к храмовому искусству, а вернее, особому виду храмового ремесла, и широко применялась для изготовления изображений божеств разных размеров, использовавшихся во время религиозных празднеств (там же: 103).

\section{Аппликационные свитки в фондах Национального музея Тувы}

В фондах Национального музея Тувы хранятся три единицы хранения буддийских свитков, выполненных техникой аппликации.

В книге поступлений № 2 (дубликат 2) за порядковым номером 3677 от 21.07.1960 г. зафиксирован свиток с изображением Будды Шакьямуни. В графе о наименовании музейного предмета имеется запись: «Бурган Башкы Туваан. Изображение вышитое цзветной аппликацией» (фото 1).

В книге поступлений № 1 под номером 1666 от 27.03. 1954 г. значится музейный предмет с наименованием: «Занавеска хурэ с изображением человеческих голов окаймлена шелковыми нитками, оборотная сторона -холст» (фото 2).

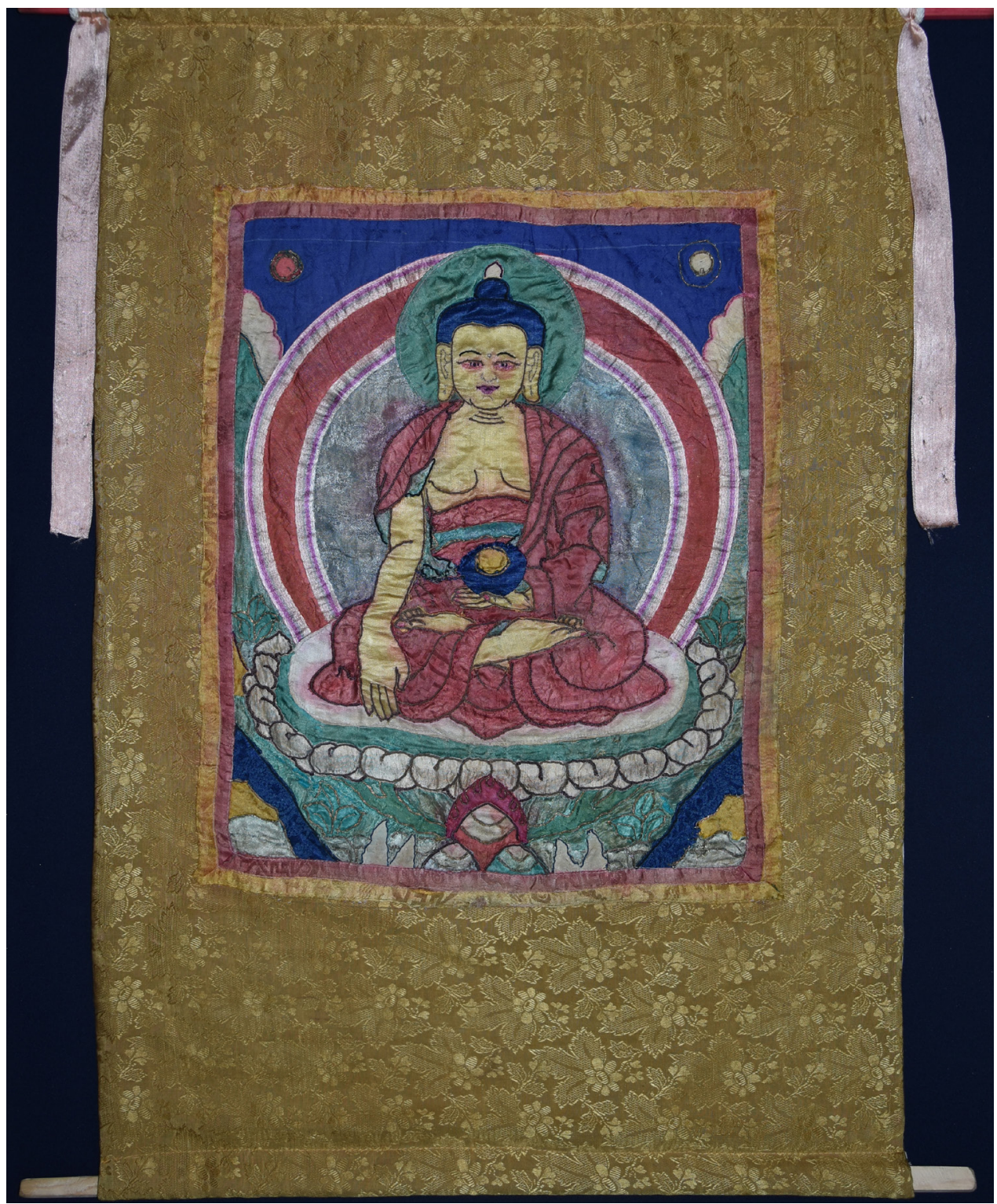

Фото 1. Аппликационное изображение Будды Шакьямуни. Фото А. Д. Куулар, 2019 г. Photo 1. An appliqué with Gautama Buddha. Photo A. D. Kuular, 2019. 


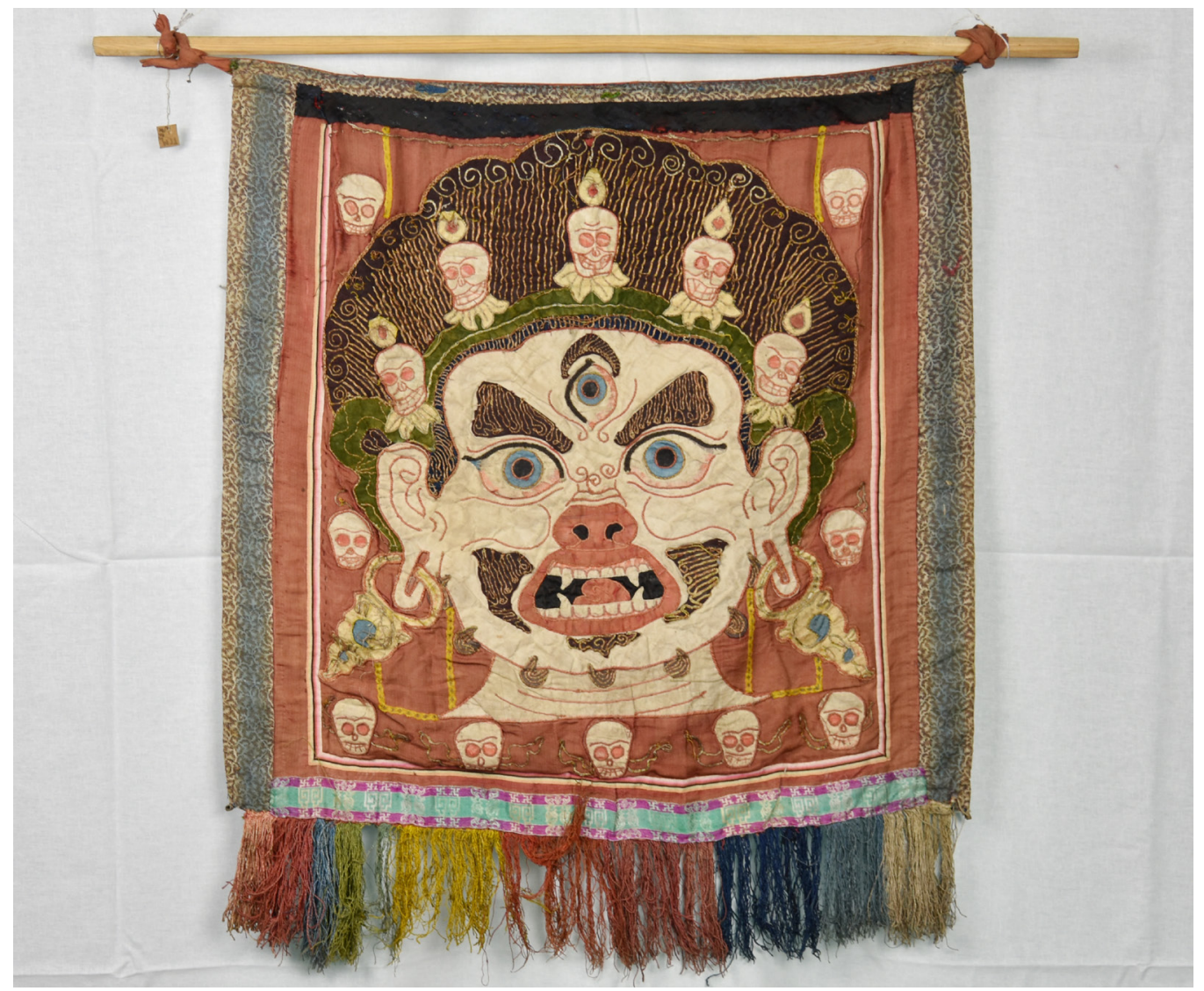

Фото 2. Аппликационное изображение головы докшита. Фото А. Д. Куулар, 2019 г.

Photo 2. An appliqué with the head of a dharmapāla. Photo by A.D. Kuular, 2019.

На этой аппликации изображена голова грозного докшита или дхармапалы, которые в буддийской мифологии представляют защитников учения и его последователей (Буддизм, 1992: 117, 121).

Еще один аппликационный свиток (фото 3) экспонируется в зале № 6, где развернута постоянная выставка буддийской коллекции под названием «Буддизм в Туве». В книгах поступлений музея информация об этом свитке не обнаружена.

Вероятнее всего, этот свиток, наряду с изображением Будды Шакьямуни, также была сдан в хранилище музея в июне 1960 г., вместе с другими многочисленными предметами буддийского культа, после конфискации имущества молитвенных юрт, располагавшихся в местечке Кызыл-Чыраа Дзун- Хемчикского района и функционировавших с 1946 по 1960 гг.

Окладом этого свитка служит коричневый плотный шелк очень хорошего качества. На нем вытканы восточный символ «узел счастья» (олчей удазыны), чередующийся с другим знаком, состоящим из двух пересеченных квадратных или ромбических фигур. Этот знак в качестве символа крепких семейнобрачных отношений до настоящего широко используется у монголов.

На иконе изображено трехликое божество белого цвета с четырьмя руками, облаченное в прекрасное одеяние. Изображение божества обрамлено двойным ореолом святости: первый - розового цвета (у трехликой головы божества), второй - ярко красного цвета (обрамляет все тело божества).

Изображенное на свитке божество имеет сложный головной убор. На верхней части прически, где, в соответствии с буддийской традицией должна быть ушниша ${ }^{1}$, изображены три дополнительные лики красного цвета. Возможно, эти три головы, одновременно выполняют функцию своеобразного головного убора данного божества, символизирующего «три прибежища» или «три драгоценности» буддизма: Будду, его Учение и монашескую общину.

${ }^{1}$ Ушниша в буддизме - выпуклость на макушке головы, являющаяся символом достигнутого просветления. Согласно буддийскому канону, ушниша входит в число обязательных иконографических признаков буддизма (Буддизм, 1992: 255). 


\section{НОВЫЕ ИССЛЕДОВАНИЯ ТУВЫ}

www.nit.tuva.asia

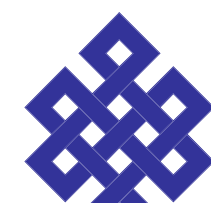

№2

\section{THE NEW RESEARCH OF TUVA}

2019
Novye issledovaniia Tuvy

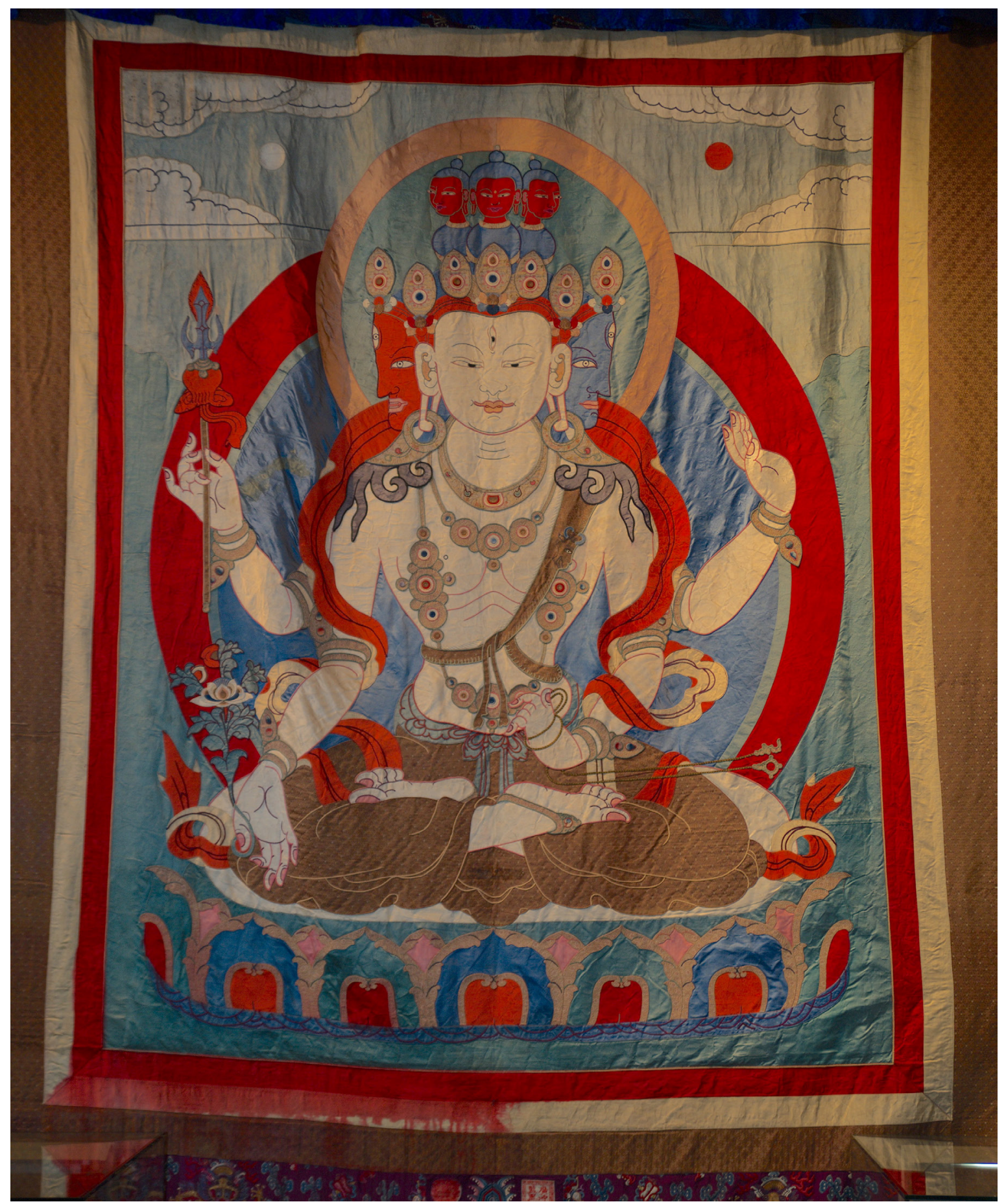

Фото 3. Аппликационное изображение Будды Амогхапаши. Фото А. Д. Куулар, 2019 г.

Photo 3. An appliqué with Amoghpasha Buddha. Photo by A. D. Kuular, 2019.

Кроме этого, божество имеет головное украшение - диадему в виде венца, которое служит символом королевского (царского, ханского) происхождения или достоинства. Иногда его определяют как знак избранности. Она состоит из семи видимых и двух невидимых зубцов, украшенных драгоценностями синего и красного цветов. Всего зубцов у диадемы - девять, следовательно, на каждый лик божества приходится по три зубца. Девять зубцов диадемы, вероятнее всего, символизируют девять уровней Учения буддизма.

Три лика божества выполнены в трех разных цветах. Главное его лицо белого цвета как и все его тело; правое - красного, обычно таковым изображался лик Будды Амитабхи, левое - синего, в традиционном цвете головы Ваджрапани в гневном аспекте. Каждое из трех ликов божества имеет по три глаза. Правому 
НОВЫЕ ИССЛЕДОВАНИЯ ТУВЫ

www.nit.tuva.asia

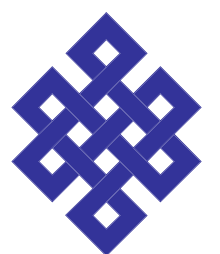

\section{THE NEW RESEARCH OF TUVA}

Novye issledovaniia Tuvy

и левому ликам божества придан грозный вид. Центральное лицо божества выражает спокойствие, на губах угадывается легкая улыбка, глаза излучают теплый, полный сострадания, безгранично милостивый взгляд. Правая нижняя рука с розовым лотосом, изображает распространенный жест «даяние», или по-тибетски «дарования высшего» (Терентьев, 2004: 56). Подобное расположение руки еще называют жестом «варада-мудры» (жест дарения блага) (Буддизм, 2010: 448). Правая верхняя рука изображает жест трех драгоценностей и сжимает один из самых значимых и распространенных символов - трезубец со штандартом. В левой нижней руке божества имеется атрибут, изображающийся в руках множества гневных божеств - веревку с крюком - петлю или аркан. На конце стилизованного аркана изображен китайский символ бесконечности - инь и ян. Левая верхняя рука божества изображает жест дарования безопасности, которую в тибетской иконографической традиции отождествляют с жестом дарования защиты (там же).

Божество изображено восседающим на белом полукруге, похожем на лунный диск. В связи с этим, вспоминается еще одна эманация Авалокитешвары - покровителя Тибета Ченрезик Чакчжипа, который в этой ипостаси всегда изображается сидящим на диске луны, поддерживающимся распустившимися лепестками лотоса (Буддизм, 2010: 448). Лепестки цветка чередуются: красный с оранжевым и синий с зеленым. Центральный или главный облик божества наделен набедренной повязкой коричневого цвета. С его плеч, обвивая руки, ниспадает шелковый шарф; в ушах - круглые серьги; на груди, на уровне пупка, у предплечья, на запястьях, а также на ногах - ожерелья и браслеты. Через левое плечо перекинута стилизованная шкура антилопы, а возможно и оленя.

Такого же типа украшения можно обнаружить на буддийских скульптурных и живописных изображениях выдающегося религиозного деятеля средневековой Монголии Дзанабадзара. Следовательно, можно сделать вывод, что данная аппликационная картина была изготовлена по правилам и опыту монгольских мастеров. Н.-О. Цултэм утверждает, что украшения божеств и бодхисатв, изготавливаемых монгольскими мастерами, часто повторяли монгольские узоры и орнамент (Цултэм, 1984: 82).

При оформлении общего фона аппликационной иконы автор работы, видимо, строго придерживался правил традиций буддийской живописи, подразделив картину на три части. В верхней расположил облака, небо, солнце и луну. На середине - горы, деревья, землю. Нижняя часть иконы украшена специальным китайским шелком сложной технологии. На нем изображены драконы - символы власти.

Лик божества, вероятнее всего, выполнено в соответствии с установленными в буддийской живописи правилами. Высота лица божества равна его ширине. Овал лица округлый и тем самым уподоблен полной луне.

Несмотря на близость к манере и стилю монгольских мастеров в изображении, тем не менее, мы наблюдаем здесь и особые нюансы. Например, форма носа описываемого божества отличается от формы носа монгольских изображений. Если монгольские мастера изображаемым божествам придавали прямую форму носа или с легкой горбинкой, то у данного божества форма носа укороченный, даже чуть вздернутый, т. е. уподоблен форме носа большинства коренных жителей центральной Тувы.

Остается раскрыть вопрос о конкретном персонаже, изображенном на этом свитке.

Судя по белому цвета тела, четырем рукам и множеству лиц, можно предположить, что на большой аппликации присутствует изображение одной из ипостасей бодхисаттвы безграничного сострадания Авалокитешвары (санскр. Avalokitesvara, тиб. Ченрези, Ченрезиг / Chenrezig) - иными словами, бодхисаттва семейства Падма (Буддизм, 2010: 448).

По причине того, что данная икона является единственной аппликационной храмовой картиной большого объема, имеющейся на территории Тувы, она представляет собой большую ценность как часть культурного наследия республики. Об этом свидетельствует тот факт, что во время одного массового религиозного мероприятия, проводившегося в августе 2005 г. в г. один из высших иерархов традиции Гелугпа Богдо-геген IX Халха Джецуна Дамба Ринпоче обратил внимание на эту икону и дал высокую оценку ее изготовлению.

В настоящее время руководство Национального музея Тувы ведет работу по подготовке к изданию каталога буддийских предметов и изображений божеств, хранящихся в его фондах. В осуществлении этой работы музею оказывает помощь старший научный сотрудник отдела Востока Государственного Эрмитажа, хранитель монгольской, тибетской и хотанской коллекции, кандидат исторических наук Ю. И. Елихина. Как эксперт в области буддийского искусства, изображение божества, запечатленное 
на вышеописанном большом свитке тувинского музея, Ю. И. Елихина определила как Авалокитешвару Амогхапашу. Другие названия бодхисаттвы сострадания: Амогхапаша Локешвара или Падмани Локешвара.

Амогхапаша Локешвара или «Господь мира Благой Аркан» является эманацией Авалокитешвары. Он обычно изображается также бодхисаттвой с телом белого цвета, правый лик красный, левый - синий, имеет четыре руки, правой верхней рукой он творит абхая-мудру (защиту), нижней - мудру отдачи. В левой верхней руке держит тришулу с бунчуком, нижняя рука находится на уровне живота. Во всех остальных иконографических деталях этот дхьяни-бодхисаттва подобен вышеуказанным изображениям Авалокитешвары (Буддизм, 2010: 448-450).

\section{Заключение}

Итак, самый большой буддийский свиток Национального музея Республики Тыва, также, как и два других, представляет собой огромную религиозную и искусствоведческую ценность и является уникальным объектом культурного наследия народов Республики Тыва. Без сомнения он выполнен мастерами аппликации высокого уровня. В нем нет ни одной детали, которая отклонялась бы от правил изображения буддийских божеств - даже самые маленькие штрихи строго выдержаны в духе установленной буддийской регламентации. Во время работы над изготовлением иконы мастерами соблюдены соотношение разных деталей, система координат, цветовая гамма, композиция рисунка и сложная система мифологии, знаний и трактовки.

После изучения соответствующей литературы и обобщения знаний, полученных при общении со знатоками буддийского изобразительного искусства, мы пришли к выводу, что данная религиозная аппликация, возможно, была изготовлена на территории Тувы усилиями местных мастеров с использованием китайского материала. Образцами для изображения божества, послужили живописные иконы и статуэтки, изготовленные в литейных мастерских Монголии по эскизам и формам великого Дзанабазара, которые в свое время широко доставлялись в буддийские монастыри, воздвигнутые по всему ареалу распространения северного буддизма, в том числе и на территорию Тувы, а затем сохранившиеся и использовавшиеся, в тувинских хурээ со второй половины XVIII и до начала XX века.

Помимо этого свитка и другие предметы буддийского искусства, которые являются достоянием фондов Национального музея Тувы, нуждаются в научном описании и обработке. Но трудность научного описания, как справедливо отметил А. А. Терентьев, заключается в чрезвычайной сложности самого предмета буддийской иконографии (Терентьев, 2004: 18).

\section{СПИСОК ЛИТЕРАТУРЫ}

Берзин, А. (1992) Тибетский буддизм: История и перспективы развития. Волгоград : Полиграфическое предприятие «Офсет». 32 с.

Буддизм (1992) : Словарь / Л. Л. Абаева, В. П. Андросов, Э. П. Бакаева и др.; под общ. ред. Н. Л. Жуковской и др. М. : Республика. 287 с.

Буддизм (2010) : иллюстрированная энциклопедия / отв. ред. А. Богословский. М. : Эксмо. 576 с.

Будегечи, Т. Б. (1995) Художественное наследие тувинцев. М. : Внешторгиздат. 152 с.

Будегечиева, Т. Б. (2018) Тувинская культура: материальное и духовное, традиции и новации. Кызыл : Издательство ТувГУ. 115 с.

Кузьмин, С. Л. (2016) Буддизм как традиционная религия России : историческая основа и перспективы // Буддизм в третьем тысячелетии : тенденции и перспективы развития. Материалы Международной научной конференции (7-9 сентября 2016 г.) : в 2 т. / отв. ред. М. М.-Б. Харунова, О. М. Хомушку. Кызыл : Изд-во ТувГУ. Т. І. 340 с. С. $24-31$.

Монгуш, М. В. (2001) История буддизма в Туве (вторая половина VI - конец XX в.). Новосибирск : Наука. 200 с.

Терентьев, А. А. (2004) Определитель буддийских изображений. СПб. : Нартанг. 304 с.

Цултэм, Н.-О. (1982) Искусство Монголии. М. : Изобразительное искусство. 232 с.

Дата поступления: 12.03.2019 г. 


\section{REFERENCES}

Berzin, A. (1992) Tibetskii buddizm: Istoriia i perspektivy razvitiia [Tibetan Buddhism: History and prospects]. Volgograd, Poligraficheskoe predpriiatie «Ofset». 32 p. (In Russ.).

Buddizm : Slovar' [Buddhism: a Dictionary] (1992) / L. L. Abaeva, V. P. Androsov, E. P. Bakaeva et al., ed. by N. L. Zhukovskaya et al. Moscow, Respublika. 287 p. (In Russ.).

Buddizm : illiustrirovannaia entsiklopediia [Buddhism: an illustrated encyclopedia] (2010) / ed. by A. Bogoslovskii. Moscow, Eksmo. 576 p. (In Russ.).

Budegechi, T. B. (1995) Khudozhestvennoe nasledie tuvintsev [The artistic heritage of Tuvans]. Moscow, Vneshtorgizdat. 152 p.(In Russ.).

Budegechieva, T. B. (2018) Tuvinskaia kul'tura: material'noe i dukhovnoe, traditsii i novatsii [Tuvan culture: the material and spiritual, traditions and innovations]. Kyzyl, TuvGU Publ. 115 p. (In Russ.).

Kuz'min, S. L. (2016) Buddizm kak traditsionnaia religiia Rossii: istoricheskaia osnova i perspektivy [Buddhism as a traditional religion of Russia: historical basis and prospects]. In: Buddizm v tret'em tysiacheletii: tendentsii i perspektivy razvitiia [Buddhism in the third Millennium: trends and prospects]. Proceedings of an international conference (7-9 September 2016): in 2 vols. / ed. by M. M.-B. Kharunova and O. M. Khomushku. Kyzyl, TuvGU Publ. Vol. I. 340 p. Pp. 24-31. (In Russ.).

Mongush, M. V. (2001) Istoriia buddizma v Tuve (vtoraia polovina VI - konets XX v.) [A history of Buddhism in Tuva from the latter half of 6th to the end of the 20th century)]. Novosibirsk, Nauka. 200 p. (In Russ.).

Terent'ev, A. A. (2004) Opredelitel' buddiiskikh izobrazhenii [A guide to Buddhist images]. St. Petersburg, Nartang. 304 p. (In Russ.).

Tsultem, N.-O. (1982) Iskusstvo Mongolii [The art of Mongolia]. Moscow, Izobrazitel'noe iskusstvo. 232 p. (In Russ.).

Submission date: 12.03 .2019 . 